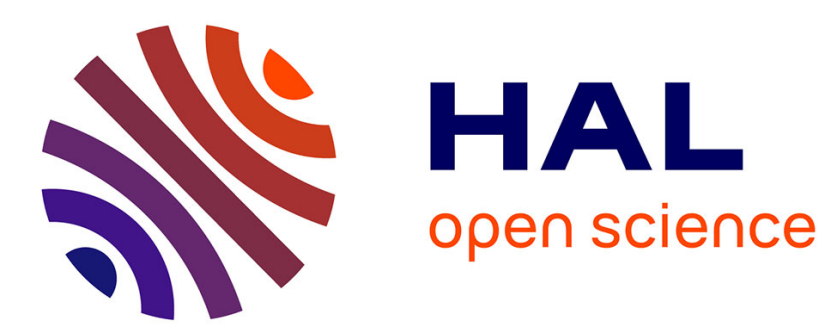

\title{
Fertility from Urban Wastes? The Case for Composting in Great Britain, 1920s-1960s \\ Arnaud Page
}

\section{To cite this version:}

Arnaud Page. Fertility from Urban Wastes? The Case for Composting in Great Britain, 1920s1960s. Environment and History, 2019, 25 (1), pp.3-22. 10.3197/096734018X15137949592070 . hal03374112

\section{HAL Id: hal-03374112 \\ https://hal.science/hal-03374112}

Submitted on 13 Oct 2021

HAL is a multi-disciplinary open access archive for the deposit and dissemination of scientific research documents, whether they are published or not. The documents may come from teaching and research institutions in France or abroad, or from public or private research centers.
L'archive ouverte pluridisciplinaire HAL, est destinée au dépôt et à la diffusion de documents scientifiques de niveau recherche, publiés ou non, émanant des établissements d'enseignement et de recherche français ou étrangers, des laboratoires publics ou privés. 


\section{Author's version.}

Article published in Environment and History, vol. 25, n 1, 2019, pp. 3-22.

\section{"Fertility from Urban Wastes? The case for composting in Great Britain, 1920s-1960s".}

\section{Arnaud Page, Sorbonne University, HDEA}

This paper analyses the interest which developed in Great Britain around composting from the late 1920s. It argues that before the current vogue for composting, the technique attracted considerable attention in the middle of the twentieth century and that interest in this technology was not limited to a few 'mystical' members of the organic movement. This paper also analyses the role of an institution called the Natural Resources (Technical) Committee and attempts to show that opposition in Whitehall played a key role in the marginalisation of this technology. It thus suggests that the rise of the 'hegemony of disposal' in the twentieth century did not go uncontested and that it was not a purely technical and inexorable movement. The example of composting thus shows that the birth of a 'throwaway society' was not as consensual as usually described and rather than the result of a widespread aversion to refuse, it should be seen as the result of political decisions, themselves informed by a specific type of quantitative and reductionist type of expertise.

Large-scale composting, a practice still riddled with technical difficulties and which has recently been described as the 'final frontier of recycling', is nevertheless an increasingly popular method of dealing with domestic and municipal refuse. ${ }^{1}$ Apart from the most famous examples (the city of San Francisco claims to compost all its organic waste), there is now a widespread belief that this method of processing refuse is one that should be encouraged and developed. In England for example, the amount of household and other organic waste being composted at a municipal level more than doubled between 2010 and in $2014 .^{2}$ The desirability of encouraging this technology is predicated on the increasing and seemingly out-of-control amount of waste produced by modern societies, as well as the need to find alternatives to energy-intensive synthetic fertilisers. A symbol of a more 'circular' economy and use of resources, it is presented as a way to counter the unsustainability of our modern 'throwaway culture'. ${ }^{3}$ As such, municipal composting is often described as a practice that was, like most other forms of large-scale recycling, 'invented' in the 1970s and thus is seen as characteristic of a supposedly new attitude towards modernity and its unprecedented 'crisis of waste $^{\prime 4}$.

\footnotetext{
"Bloomberg Plan Aims to Require Food Composting", New York Times, 16 June 2013.
}

2 Department for Environment, Food and Rural Affairs, 'Statistics on waste managed by local authorities in England in 2014-2015', 1 December 2015 , https://www.gov.uk/government/uploads/system/uploads/attachment data/file/481771/Stats Notice Nov 2015.pdf, accessed 24 June 2016.

3 See for example 'Call for end to "throwaway society", BBC news, 24 July 2014, http://www.bbc.com/news/scienceenvironment-28460705, accessed 20 June 2016. The concept of a 'throwaway' society seems to have been used for the first time in the mid-1950s. It was given wider resonance, and became associated with a critique of consumerism, in 1960 by the American journalist Vance Packard. Vance Packard, The Waste Makers, New York: David McKay, 1960.

4 See for example R. A. Slater and J. Frederickson, 'Composting municipal waste in the UK: some lessons from 
In parallel with the growing public interest and concern with environmental issues, historians have for the past few decades sought to recover waste from the bins of the past and have actually shown that what constitutes 'waste' and what to do with it have always been key and difficult questions, faced with challenges and contestations. ${ }^{5}$ As Martin O'Brien has argued, 'industrial societies are and always have been 'throwaway societies' and (this) ejecting process has been subject to periodic evaluation and critique on a scale directly comparable with today's common sense complaints'. ${ }^{6}$ Historians have thus documented how recycling and concerns over waste are not specific to contemporary society. ${ }^{7}$ If it is acknowledged that recycling is obviously not a recent invention, it is however generally agreed that the hundred years or so between 1870 and 1970 were marked by the ebbing of such attempts at reusing and the rising 'hegemony of disposal'. ${ }^{8}$ This period was indeed characterised, especially in Great Britain, by a municipalisation of waste collection and disposal, by the establishment of more rigorous standards and by the preeminence of hygiene and health concerns. This process, called the 'Refuse Revolution' by historian Bill Luckin, thus saw the rise of incineration and then 'controlled tipping' (or 'sanitary landfilling') as the leading methods in the treatment of domestic waste. ${ }^{9}$ This was accompanied by a reconceptualisation of rubbish as something that was no longer valuable but as something worthless, unhygienic and potentially dangerous, and therefore by the decline of recycling mindsets in the country.

This picture has been qualified by historians who have shown how the two world wars were exceptions to the rise of this new waste regime, and how they were marked by important levels of awareness of the potential value of waste and by ambitious recycling schemes. ${ }^{10}$ The promotion of recycling during the two world wars is nonetheless described as being mostly tied to the situations of scarcity produced by exceptional circumstances. These events thus provide interruptions and aberrations but do not really destabilise the main narrative, marked by the triumph of disposal, itself the product of a new, more professional and 'modern' way of dealing with waste. The aim of this paper is not to deny the rising 'hegemony of disposal' (in the use of landfills or controlled tipping) as the preferred way of dealing with household waste, but to argue that the rise of this 'throwaway culture' was not a natural phenomenon, where rationalisation and modernisation necessarily dictated that rubbish became conceptualised as uniformly noxious and useless, and that salvaging came to be seen as a pre-modern practice. This paper intends to show that the meaning of such terms as 'rationalisation' or modernisation could be contested and that these were not unilinear and consensual processes. Through the example of the rise and fall of the composting movement in $20^{\text {th }}$ century Britain, it attempts to question the existence of a homogenous and uniform attitude of neglect towards rubbish in Great Britain before the rise of environmental concerns. It shows that while composting is today presented as a practice that was invented in the 1970s, it attracted

Europe', Resources, Conservation and Recycling 32 (2001): 359-374. Notable exceptions, mostly focusing on the United States, include Joel Tarr, 'From city to farm: urban wastes and the American farmer', Agricultural History 49 (1975): 598-612 and Barton Blum, 'Composting and the roots of sustainable agriculture', Agricultural History 66 (1992): 171-188.

5 Sabine Barles \& Laurence Lestel, 'The Nitrogen question : Urbanization, industrialization, and river quality in Paris, 1830-1939', Journal of Urban History 33 (2007): 794-812; Martin Melosi, The Sanitary City. Urban infrastructure in America from Colonial times to the Present (Baltimore : The Johns Hopkins University Press, Baltimore, 2000); Martin Melosi, Garbage in the Cities: Refuse, Reform and the Environment (Pittsburgh: University of Pittsburgh Press, 2005); Sabine Barles, 'History of waste management and the social and cultural representations of waste', in M. Agnoletti and S. Neri Serneri (eds.), The Basic World of Environmental History, pp. 199-226 (Heidelberg: Springer Verlag, 2014).

6 Martin O'Brien, A Crisis of Waste? Understanding the Rubbish Society (London: Routledge, 2008): 6.

7 Timothy Cooper, 'War on waste? The politics of waste and recycling in post-war Britain, 1950-1975', Capitalism Nature Socialism 20 (2009): 53-72.

8 Timothy Cooper, 'Modernity and the politics of waste in Britain', in P. Warde, and S. Soerlin (eds.), Nature's End: History and the Environment, pp. 247-272 (Basingstoke: Palgrave Macmillan, 2009).

9 Bill Luckin, 'Pollution in the City', in Martin Daunton (ed.), The Cambridge Urban History of Britain, vol. III, 18401950, pp. 220-221 (Cambridge: Cambridge University Press, 2000).

10 Timothy Cooper, 'Challenging the "Refuse Revolution": War, waste and the rediscovery of recycling, 1900-1950', Historical Research 81 (2008): 710-731; Peter Thorsheim, Waste into Weapons: Recycling in Britain during the Second World War (Cambridge: Cambridge University Press, 2015). 
considerable interest from the late 1920s. It also seeks to argue that interest in this technology was not limited to a few 'mystical' members of the organic movement, as the question was in fact addressed by a wider community of sanitary engineers, agricultural scientists and public health specialists. This study of the movement in favour of composting therefore throws doubt on the idea that only at the end of the twentieth century have concerns around waste been raised and initiatives devised to 'close the nutrient loop' by recycling organic waste. This paper thus seeks to add to recent interventions which have shown that moderns did not unknowingly 'slip' into a throwaway culture, as if scientists and decision-makers had been unaware of environmental problems in general and of the issue of waste in particular until a sudden awakening in the late twentieth century. ${ }^{11}$

The example of composting thus provides an interesting perspective on the history of early warnings and contestations of the 'throwaway society' but also sheds light on the processes and decisions which led these voices to become less and less audible. Apart from a presentation of the composting movement, this paper indeed also seeks to analyse the reasons for its marginalisation. Considerations of cost were obviously crucial and were an important factor in the widespread adoption of controlled tipping as the cheapest method of refuse disposal. This paper, however, also attempts to show that opposition in Whitehall played a key role in the marginalisation of this technology. The collection and disposal of town refuse being a local prerogative in Great Britain, supervision by the government is traditionally described as distant and of little influence. ${ }^{12}$ The paper argues that in the case of composting, opposition from the State was decisive. It does so by showing the role played by a relatively unknown official body, the Natural Resources (Technical) Committee, which produced a very hostile report on composting in the mid-1950s, that was then used for more than twenty years by Whitehall to bury the practice of composting and to systematically dissuade local authorities from investing in this technology. The analysis of the work of the Committee and its use by both the Ministry of Housing and Local Governement and the Ministry of Agriculture, show the rise of quantitative indicators, and of nitrogen in particular, which were used to assess both agricultural and waste-management policies. It thus suggests that the 'Refuse Revolution' was not a purely technical and inexorable movement, as not all engineers subscribed uncritically to the superiority of disposal, and argues that its rise should therefore also be seen as the result of increasingly centralized political decisions, themselves informed by a specific quantitative and reductionist type of expertise

\section{House refuse as valueless?}

In the $19^{\text {th }}$ century, the question of large-scale recycling had focused mostly on the sewage of towns, and the second half of the nineteenth century was marked by protracted discussions and attempts to recycle these wastes for agricultural purposes. ${ }^{13}$ In the field of house refuse, however, the second half of the nineteenth century corresponded to a clear decline in salvaging practices, as incinerators,

11 Christophe Bonneuil \& Jean-Baptiste Fressoz, L'Evenement Anthropocène: La Terre, l'histoire et nous (Paris: Seuil, 2013): 92-98. English translation: The Shock of the Anthropocene: The Earth, History and Us (London: Verso, 2016).

12 Raymond G. Stokes et. al., The Business of Waste: Great Britain and Germany, 1945 to the Present (Cambridge: Cambridge University Press, 2013): 51.

13 There is a vast literature devoted to the subject. See in particular Nicholas Goddard, "'A mine of wealth"'? The Victorians and the agricultural value of sewage', Journal of Historical Geography 22 (1996): 274-290; John Sheail, 'Town wastes, agricultural sustainability and Victorian sewage', Urban History 23 (1996): 189-210; Erland Marald, 'Everything Circulates: Agricultural chemistry and recycling theories in the second half of the nineteenth century', Environment and History 8 (2002): 65-84. 
destructors and landfill techniques became adopted by English local authorities. ${ }^{14}$ With rising sanitary standards and the establishment of municipal waste services the 'Refuse Revolution' was characterised by an attitude that saw the destruction and disposal of rubbish as 'modern and progressive', relegating salvaging to something of an obsolete practice. ${ }^{15}$

The First World War destabilised this paradigm by initiating what has been termed 'a brief challenge to the nascent throwaway society'. ${ }^{16}$ Although the political supervision of recycling was somehow lax and belated (a National Salvage Council was not formed until March 1918), the numerous schemes for the salvaging of cotton, rags and metals set up by local authorities complexified prevailing conceptions of waste. As the author of a pamphlet entitled Wealth from Waste wrote in 1918: 'Before the war, everything was so different; in the full enjoyment of unparalleled prosperity, extravagance and waste were rampant in the land. (...) The War, with its colossal requirements in men, munitions, material and money has changed much of that, and the era of retrenchment, frugality, economy, and thrift has dawned, whilst the gospel of the prevention of waste is being preached at every turn'. ${ }^{17}$

The war thus instilled the sense among sanitary and other experts that their task should be oriented towards efficient recovery and not just towards disposal, which casts doubt on the idea that the 'throwaway ethic' completely triumphed and disposed of the 'recycling ethic' in the first three decades of the twentieth century. ${ }^{18}$ In 1922, even a champion of artificial fertilizers like Sir John Russell, from the Rothamsted Experimental Station, argued that municipal waste should be used to fertilise agricultural lands, rather than being tipped or burnt, two practices which he described as obsolete and not 'modern' enough :

'Most of us have seen and smelt the huge refuse dumps that have grown up round London, and if the fertiliser value could be assessed by the disagreeable odour the case for town refuse would be sufficiently convincing. As might be expected, there is an increasing reluctance on the part of country people to allow the countryside to be disfigured in this way. A less objectional method than that of dumping in country districts is to incinerate the refuse, but this is costly, and of course is sheer waste. More up-to-date town authorities are now making an effort to dispose of their refuse in a better and more useful way, and some are adding other wastes and crushing the whole for use as a fertiliser. ${ }^{19}$

Considerations of cost-effectiveness and the difficulty to find stable demand and markets for salvage material meant, however, that most of these schemes were short-lived and that controlled tipping became the dominant form of refuse disposal in the interwar period. ${ }^{20}$ However, the question of the salvaging of house refuse was never really completely forgotten and started to be discussed again in the late 1920s with the introduction of composting. The Netherlands started experiments on the question in 1929, and in Great Britain, discussions mostly focused on the process developed at the same time in India by agricultural scientist Albert Howard. Howard's 'Indore' process was intended to develop composting on a large scale and consisted in superposing layers of vegetable material and waste with animal manure and ashes in large pits that were turned manually at

\footnotetext{
14 One could however mention a few projects, such as the Garden Cities of Ebenezer Howard, who proposed to return all town refuse to adjoining agricultural lands. Ebenezer Howard, Garden Cities of Tomorrow (London: Swan Sonnenschein, 1902): 25.

15 Bill Luckin, 'Pollution in the City', pp. 220-221; Cooper, 'Modernity and the politics of waste in Britain', pp. 261-262.

16 Cooper, 'Challenging the "Refuse Revolution"': 710.

17 Henry J. Spooner, Wealth from Waste: Elimination of Waste a World Problem (London: Routledge, 1918 ): 3.

18 Cooper, 'Challenging the 'Refuse Revolution'": 719

19 E. John Russell, 'The Possibility of Using Town Refuse as Manure', Journal of the Ministry of Agriculture 29 (1922): 685-691.

20 Timothy Cooper, 'Burying the "Refuse Revolution": The rise of controlled tipping in Britain, 1920-1960', Environment and Planning A 42 (2010): 1033-1048.
} 
intervals. The scheme was to prove very successful, and was taken up by sewage expert Gilbert J. Fowler, who transplanted it to other Indian urban areas, for example in Mysore city, which had a population of more than $100,000 .^{21}$

Howard was to become in the 1940s the towering reference of the members of the emerging organic movement, who made a vocal case for composting and claimed that Howard's work had always been wrongfully ignored by agricultural researchers and 'mainstream science'. ${ }^{22}$ In fact, in the 1930s, there was considerable interest in his ideas and the technologies that he developed. Composting was promoted by agricultural officers in Africa, and there were for example more than 10,000 compost pits in Kenya by the late $1930 \mathrm{~s}^{23}$ In Malaya and Singapore, under the impulsion of the Chief Health Officer, large-scale experiments were conducted and numerous rural incinerators were replaced by composting schemes. ${ }^{24}$ Apart from India, it was probably in South Africa that Howard's work was the most influential: during the War, the South African Department of Agriculture launched a national campaign to develop urban composting, and by 1949, more than a hundred municipal authorities had adopted composting as their chief method of refuse and sewage disposal. $^{25}$

In Great Britain too, contrary to the 'myth of neglect', Howard's work was actually often carefully studied and debated, even by the representatives of mainstream agricultural science. ${ }^{26}$ Thus, when Howard was invited in 1933 to present his work to the Society of Arts, he was praised by the members in the audience who thought that Britain 'should be forced before very long to consider a return to the Chinese methods' and that 'the world could not afford to go on casting its phosphates into the sea' ${ }^{27}$ The session was chaired by no other than Daniel Hall, Chief Scientific Adviser to the Ministry of Agriculture, who saw in Howard's method a work 'of prime scientific and economic importance', which should be considered as a way of preventing erosion and the 'decay of humus' that were becoming growing concerns in the interwar period. ${ }^{28}$ The question of the adaptation and importation of these methods into Great Britain thus started to be raised in the 1930s, and a few plants were set up, notably in Maidenhead, Berkshire and Leatherhead, Surrey, where house refuse was subjected to screening, magnetic separation, pulverisation, was then mixed with sewage sludge, and left to mature for several months, before being sold as compost by the municipal authority. ${ }^{29}$

21 Gilbert J. Fowler, An Introduction to the Biochemistry of Nitrogen Conservation (London: Edward Arnold \& co., 1934): 245.

22 On Howard see Philip Conford, 'The Alchemy of waste : The Impact of Asian farming on the British organic movement', Rural History 6 (1995): 103-114 and Gregory A. Barton, 'Albert Howard and the decolonisation of science: From the Raj to organic farming', in Brett M. Bennett \& Joseph M. Hodge (eds.), Science and Empire: Knowledge and Networks of Science across the British Empire, 1800-1970, pp. 163-186 (Palgrave: Macmillan, 2011). Philip Conford, The Origins of the Organic Movement (Edinburgh: Floris Books, 2001), pp. 53-59.

23 Mary Tiffen, Michael Mortimore \& Francis Gichuki, More People, Less Erosion: Environmental Recovery in Kenya (Nairobi: ACTS Press, 1994): 240.

24 Frank Stockdale, Report on a Visit to Malaya, Java, Sumatra and Ceylon (London: Colonial Advisory Council of Agriculture and Animal Health, 1939), p. 99; J. W. Scharff, 'A Vital Element in Agriculture', Journal of the Royal African Society, 41 (1942): 114-118.

25 J. P. J. Van Vuren, Soil Fertility and Sewage (London: Faber and Faber, 1949): 9-10, 57 \& 59.

26 Philip Conford, 'The myth of neglect: responses to the early organic movement, 1930-1950', The Agricultural History Review 50 (2002): 89-106.

27 'The Waste products of agriculture: Their utilization as humus', Journal of the Royal Society of Arts, 82 (1933): 114. Interest in the so-called 'Chinese methods' had been raised by F. H. King's Farmers of Forty Centuries or Permanent Agriculture in China (first published in 1911 but reissued in 1927 in Great Britain). In the book, King, an official from the the US Department of Agriculture, contrasted the careless attitude of the West towards its soil with the attitude of Chinese peasants, who took great care to preserve the fertility of their soils by returning all waste to the earth.

28 See for example the review by the Professor of agriculture and Head of the department of agriculture at Cambridge, F. L. Engledow, 'Review of The Waste Products of Agriculture: their Utilization as Humus', Nature 128 (1931): $854-$ 855, or A. G. Norman, 'Humus Manufacture', Nature, 132 (1933): 828-828.

29 'Manufacture of Humus by the Indore Process', Nature, 15 February 1936, 286; Y. D. Wad \& F. K. Jackson, 'Humic 
The first four decades of the twentieth century, apart from the brief interlude of the Great War, are generally described as having been marked by the triumph of the 'throwaway ethic' and of a widespread cultural and technical consensus around the desirability of disposal. ${ }^{30}$ Howard's work and the few pilot schemes of the 1930s, however, initiated a wider discussion around the not ${ }^{\mathrm{i}}$ on of waste and not everyone in Great Britain was convinced that rubbish was just something that one had to get rid of as quickly and as efficiently as possible. Indeed, the fact that 'efficiency' could not be measured only in terms of how quickly and cheaply municipalities disposed of domestic refuse, in other words that recycling and 'rationalisation' could go hand in hand, was to be illustrated during the Second World War which gave a tremendous boost to recycling practices in general, and to composting in particular.

\section{World War II, recycling and composting}

With the advent of the Second World War, Great Britain embarked on an unprecedented recycling programme. In 1939, the British government launched a large-scale salvaging campaign to make up for its shortage of raw materials, and coordinated an ambitious scheme of municipal collection. As a recent account of the period puts it, 'salvage became an essential part of the war economy': in November 1939 a Salvage Department was created within the Ministry of Supply to oversee all recycling activities. Local authorities were asked to collect salvage material while citizens were encouraged, and after 1942 required, to sort their rubbish to save useful material. Between 1939 and 1942 this large-scale recycling campaign led to the salvage of 639,000 tons of paper, 527,000 tons of iron and steel, 35,000 tons of rags and 19,000 tons of bones. ${ }^{31}$ This recycling campaign was also characterised by the widespread salvaging of kitchen wastes, nearly half a million tons of which were collected in 1944 alone. Most of these kitchen wastes were collected in 'pig-bins' which were often criticised for their smells and accused of favoring the transmission of foot and mouth disease, but the collection of food waste did not stop in most towns until $1953 .^{32}$ Importantly, the development of recycling led to the adoption of the separate collection of refuse, and after the War it was argued that these separate bins should outlive the end of the conflict, and that residents be asked to sort their ash, tins, glass and putrescible material, so that the country could take better care of its 'great organic wealth'. ${ }^{33}$ The war gave considerable impetus to composting too, mostly in private gardens and allotments, with the publication of many composting manuals, leaflets and the use of propaganda movies to instruct gardeners on how to recycle organic waste. ${ }^{34}$ The Second World War also saw the emergence of an organic movement around Lady Eve Balfour who made a strong case in The Living Soil (1943) against the widespread use of synthetic chemical fertilisers, and for the development of composting to maintain the fertility of British soils. ${ }^{35}$ As the debate between the organic school and mainstream agricultural science gained momentum in the 1940s, however, the arguments of Balfour and her followers started be dismissed by sceptics as 'mystical or esoteric'. ${ }^{36}$ Even other environmental movements were wary of being associated with

Composts and Inorganic Fertilisers', Nature, 4 April 1936, 582.

30 Timothy Cooper, 'Challenging the "Refuse Revolution": 731; J. F. M. Clark, "'The incineration of refuse if beautiful": Torquay and the introduction of municipal refuse destructors', Urban History 34 (2007): 257.

31 Thorsheim, Waste into Weapons, p. 133.

Ibid., pp. 70-74.

33 M. George \& Association for Planning and Regional Reconstruction, Wealth from Waste (London: Lund Humpfries, 1946), pp. 62-63.

34 F.H. Billington, Compost for Garden Plot or Thousand-Acre Farm: a Practical Guide to Modern Methods, (London: Faber \& Faber, 1943); F. C. King, The Compost Gardener (Kendal: Titus Wilson, 1944); Maye E. Bruce, CommonSense Compost Making: by the Quick Return Method (London: Faber\& Faber, 1945).

35 Lady Eve Balfour, The Living Soil, (London: Faber \& Faber, 1943); Friend Sykes, Humus and the Farmer (London: Faber \& Faber, 1946), pp. 225-244.

36 Conford, The Origins of the Organic Movement, p. 81. Hugh Nicol in discussion of F. C. Temple, 'Municipal manufacture of humus from habitation wastes', Journal of the Royal Society of Arts, 7 March 1941: 226. 
the 'muck and magic school', and composting came to be increasingly rejected by more orthodox agricultural researchers as resting upon scant scientific evidence. ${ }^{37}$

Attention to compost went, however, beyond the individual compost pit and was not limited to the adherents of the organic movement, as some doctors, public health specialists and engineers also pointed out the benefits of large-scale composting for the nation as a whole. ${ }^{38}$ Just before the war, some doctors had argued that Howard's experiments should be replicated on a large scale as a way to promote more 'natural' and healthier eating and this kickstarted a small debate in the pages of the British Medical Journal. ${ }^{39}$ During the war, the question was also taken up and promoted by civil engineers who had witnessed experiments in India and other parts of the Empire, and argued that Great Britain should stop wasting its organic material. One of the most enthusiastic promoters in Great Britain was F. C. Temple, a former civil engineer, who had been devising sewage systems for 30 years in India, and who argued for the widespread adoption of composting in Great Britain. ${ }^{40}$ Another was George Bransby Williams, also a civil engineer, who had worked on numerous sewerage schemes in Britain, in East Africa and in India, and who saw in 'the manufacture of fertiliser from urban wastes' a way of getting rid of 'obnoxious waste products' while helping British farmers in their efforts to feed the nation. ${ }^{41}$ The views propounded by these engineers were also generally very favourably received. When Temple advocated before the Society of Arts the development of composting in wartime Britain, most people in the audience agreed that town waste presented a unique opportunity and that it was a shame for Britain to waste this 'material which is as valuable to us as the gold in the mines to South Africa'. These messages, along with evidence of the benefits of schemes from New Zealand or South Africa led the question to have increased resonance and to be debated in Parliament as well. ${ }^{42}$

The development of recycling was of course directly related to the wartime need to encourage the reuse of all materials and of limiting waste to a minimum, and it has been claimed that the public became less enthusiastic about it once the war ended. ${ }^{43}$ If British citizens may have grown weary by the end of the conflict, there is no doubt that the period led to a very important change of attitudes and a more serious consideration of recycling, which is bound to have outlived the war. The war thus contributed to a sustained discussion around the benefits of composting and its role in the effort to improve Britain's food security by recycling some of the 'organic wealth' instead of wasting it. Whatever may have been some of the limitations, difficulties and protestations that were encountered by the different recycling campaigns, they at least proved that expert and popular attitudes towards waste were certainly not completely immutable, homogenous or blindingly adhering to the 'throwaway ethic'.

Composting after the WarThe experience of scarcity continued after the end of

37 R. H. Stoughton, in ibid:: 223. See also John Sheail's review of The Origins of the Organic Movement by Philip Conford, The Agricultural History Review 50 ( 2002): 136-137.

38 "Composting waste materials", British Medical Journal, 9 October 1954: 857; "Composting of household waste", British Medical Journal, 29 September 1956: 758. "Municipal composting in the United Kingdom", Journal of the Sanitary Engineering Division 84 (1958): 1-29.

39 Conford, The Origins of the Organic Movement, p. 130. British Medical Journal, May 13, 1939: 1004; May 20, 1939: 1056; July 29, 1939: 251-252.

40 F. C. Temple, 'Municipal manufacture of humus from habitation wastes', Journal of the Royal Society of Arts, 7 March 1941: 215-228.

41 G. B. Williams,'“Manufacture of fertiliser from urban wastes', Nature, 5 September 1942: 3801.

42 'Agriculture and Food Values', House of Lords Debate, 26 October 1943, Hansard, vol 129 cc. 291-327. 
the conflict, and the 'rediscovery of recycling' did not in fact immediately subside. The message of the organic movement was indeed not as isolated as its critics implied, as the war had made clear that such questions as Britain's food security and the need to use the country's resources more carefully and 'rationally' could no longer be ignored. If not everyone was convinced about the benefits of composting, what is clear is that there was a sustained debate about it, which complexifies the traditional picture of 1950s Great Britain as a whole nation obliviously plunging into the new 'throwaway culture'. As a rather sceptical commentator put it in the late 1950s, 'few people today will be without some idea of what composting is. ${ }^{14}$ The period was indeed marked by an increasingly vocal case in favour of composting, through the publication of several books and reports on the subject, which gave precise examples of current composting schemes in Great Britain. These technical reports laid out the conditions, constraints, technical and commercial aspects which had to be taken into account for composting to be further developed in the country. ${ }^{45}$ Many of the people making that case were connected to the Soil Association, formed in 1946 around Lady Balfour, but the question also attracted the interest of such organisations as the Association of Public Health Inspectors, the Institute of Public Cleansing or the World Health Organisation, under whose auspices some of these reports were published. ${ }^{46}$ Needless to say, there were also companies interested in this potentially fruitful venture, the most important of which, the Dano Company, had by the late 1950s installed around 60 plants throughout the world, including some in Edinburgh and Leicester.

What made composting necessary, according to its advocates, was the need to close what is now called the 'nutrient loop' between urban and rural areas: 'No longer can we afford to adopt the attitude that what is out of sight is out of mind, and that urban amenities are unrelated to food production. ${ }^{147}$ In other words, the increasing amount of waste produced by urban areas and the need to feed an ever-increasing population rendered it imperative that urban waste be put to greater use, while devising methods in line with modern sanitary requirements. ${ }^{48}$ Far from being envisioned as a throwback to premodern conditions, composting was described, in the words of the manager of Edinburgh's cleansing department, as 'a practical and hygienic means of disposal'. ${ }^{49}$ If opponents and sceptics were apt to deride composting supporters as clinging to outdated practices, those who argued in favour of composting thus took great care to present it as a more modern way of dealing with waste than controlled tipping and incineration. An advertising film made by a composting company for example used shots of refuse smouldering in a tipping site to emphasise, by contrast, the hygienic and modern nature of composting. ${ }^{50}$

One of the arguments frequently invoked against composting was that it was not adapted to the modern waste stream which, according to critics, was increasingly composed of tins, glass and paper. In fact, as supporters of composting argued, the modern waste stream contained more, not less, organic matter, due to the rapid diminution of dust and cinder in household refuse after the Second World War. ${ }^{51}$ More generally, composting was seen a way to deal with the problems brought

44 Donald P. Hopkins, Chemicals, Humus and the Soil (London: Faber \& Faber, 1957 (1945)), p. 83.

45 J. C. Wylie, Fertility from Town Wastes (London: Faber \& Faber, 1955). Interim Report of Joint Working Party on Municipal Composting (London: Association of Public Health Inspectors, 1959). A. G. Davies, Municipal Composting (London: Faber \& Faber, 1961).

46 See the extensive bibliography established in Harold B. Gotaas, Composting: Sanitary Disposal and Reclamation of Organic Wastes (Geneva: World Health Organisation, 1956), pp. 195-199 for an overview of the international dimension of research on compost.

47 Cedric Stanton Hicks, 'Foreword', in J. C. Wylie, Fertility from Town Wastes, p. 17.

48 Gotaas, Composting: Sanitary Disposal and Reclamation of Organic Wastes, p. 8.

49 N. G. Wilson, 'The Case for Composting - Practical and Hygienic', Municipal Engineering, 17 August 1962 , p. 1253.

50 Ministry of Housing and Local Government, 'Background Note for Minister's meeting with representatives of John Thompson's Compost Plant Ltd. on 11 July 1963', National Archives, Kew (hereafter NA), HLG 51/1128.

51 Between 1935 and 1968, the proportion of vegetable and putrescible matter in town refuse increased from 13 to 17 per cent. Report of the Working Party on Refuse Disposal, (London: HMSO, 1971), p. 23. 
about by modern conditions and was indeed becoming more and more relevant because of the increasing amounts of waste being generated. It was presented as a more satisfying and rational method than the 'primitive practice' of incineration, with its attendant problems of atmospheric pollution, concerns about which soared after the 1952 London Smog. ${ }^{52}$ As for controlled tipping, its prevalence in the UK had not rendered it immune to criticisms as many were concerned about the unsustainability of this practice, since tipping space around big cities was becoming scarcer and scarcer. $^{53}$

With the development of numerous schemes abroad, notably in the Netherlands, where nine new plants were set up in the 1950s, composting attracted the attention of some local authorities as a way to dispose of their refuse in the 1950s. ${ }^{54}$ The most important new initiatives were taken in Scotland, for example in Dumfriesshire, where the county engineer J. C. Wylie was one of the most enthusiastic supporters of composting. The plant opened in 1953, processed the refuse and sewage of 45,000 people and produced 550 tons of compost a year. ${ }^{55}$ The so-called 'mystical' arguments of the Soil Association understandably carried little weight with municipal authorities, who were interested in composting for very rational and technical reasons. This was for example the case in Edinburgh, where the chief method of disposal had traditionally been incineration but where, due to the cost of building a new incinerator to face the post-WWII increase in population, it had been decided to adopt composting, which processed 40 per cent of the organic domestic refuse of the city by the early 1960s. ${ }^{56}$ There was also a successful composting plant in Jersey, where the local authorities chose to adopt composting as the most efficient disposal system and the one most adapted to its particular set of circumstances (an ageing sewer system and incinerator, pollution of ground water due to septic tanks, beach pollution because of sewage, lack of tipping space and declining soil fertility). ${ }^{57}$ The case for the development of composting was thus repeatedly made in the 1950s in Great Britain, not only by the adherents of the Soil Association but by a wider community of sanitary experts and public health engineers, and the British government was therefore regularly asked if anything was done to study and develop this practice. ${ }^{58}$

\section{The Natural Resources (Technical) Committee}

The British government thus commissioned a report on the question to the Natural Resources (Technical) Committee (NRTC). The Committee, led by the zoologist Solly Zuckerman, had been set up in 1950 in a context of rising costs and shortages of basic raw materials to advise the Government on the 'conservation of materials, through economy in use, substitution and recovering

$52 \quad$ N. G. Wilson, 'Presidential Address to the International conference on public cleansing', Edinburgh, 1953, quoted in Wylie, Fertility from Town Wastes, p. 83. W. R. Shirrefs, 'Leicester's Compost Plant', Journal of the Royal Society of Promotion of Health 85 (1965): 173-177.

53 Stokes et al., The Business of Waste, pp. 76-80.

54 See for example the discussion by J. C. Wylie and other sanitary engineers at the Symposium held in September 1959 at the University of Durham : J. C. Wylie, 'Composting', in Waste Treatment: Proceedings of the Second Symposium on the Treatment of Waste Waters (Oxford: Symposium Publication Division Pergamon Press, 1960), pp. 349-366.

55 C. A. Gordon, 'Municipal Composting in the United Kingdom', Journal of the Sanitary Engineering Division: Proceedings of the American Society of Civil Engineers 1852 (1958): 1-29.

56 J. Sumner, 'Composting of Town Wastes: Report of a visit to Edinburgh on the $3^{\text {rd }}$ of February 1961', NA, HLG $51 / 1128$.

57 Gordon, 'Municipal Composting in the United Kingdom': 28.

58 See for example the debates in the House of Commons : 22 January 1957, Hansard, vol. 563 cc. $2-3$ \& 03 March 1964, vol. 690 cc. 1100-1. See also, in the press and in scientific journals: 'Soil fertility: Artificial fertilisers versus compost', The Times, 10 January 1953: 8; 'Composting of household waste', British Medical Journal, 20 September 1956: 758-760. 'Producing humus and saving the ratepayers' money', Manchester Guardian, 20 January 1959. 
from waste'.$^{59}$ During the ten years of its existence, it produced reports on such topics as sulphur, pulp production, the expansion of agriculture, or the production of pigmeat, and was asked in 1952 to inquire into the benefits of composting.

The result of the investigations of the members of the Committee, which included representatives of Imperial Chemical Industries and the Rothamsted Agricultural Station, both vocal supporters of synthetic fertilisers, was that the NRTC advocated firmly not only against the practice of composting but also against any further experiments and investigations into the matter. The main argument expressed in its 1954 report was that compost could not, by itself, cover the country's needs in the most important soil nutrients (nitrogen, phosphorus and potassium, or NPK). The Natural Resources Committee indeed assessed the value of composting and sewage in terms of the chemical composition of their end products and then compared the amount of nutrients, actually of nitrogen, that would be made available by the recycling of the entire organic matter contained in the nation's waste. The members of the Committee concluded that this was very small compared to the nitrogen that could be made available through the use of synthetic fertilisers. ${ }^{60}$

The Report shows how nitrogen had gradually become the key indicator in agricultural development and policy in Great Britain. The need for self-sufficiency prompted by the war had not only promoted recycling, it had indeed also led to a significant rise in fertiliser consumption, as the application of nitrogen in the form of sulphate of ammonia had doubled between 1939 and 1946 in Great Britain. ${ }^{61}$ Apart from advertising and extension campaigns, this result had mostly been achieved through the creation of a fertiliser subsidy, which covered around 40 per cent of farmers' fertiliser expenditure. ${ }^{62}$ Beyond the increase in production and consumption, the most interesting aspect of the new attitude of British authorities and experts regarding fertilisers was the way nitrogen came to be regarded as the ultimate, if not only, indicator of soil fertility. While the $1930 \mathrm{~s}$ had been marked by sustained attention being given to 'humus' and all the other non-chemical aspects of soils, this approach was marginalised after the Second World War, and replaced by a more abstract and statistical type of expertise, which focused its attention on the question of soil nutrients (NPK), and on nitrogen in particular. ${ }^{63}$

In 1951, before interesting itself in the question of composting, the NRTC had produced a report for the British government on the question of the 'Expansion of British agriculture', and had singled out nitrogenous fertilisers as the main lever which would enable a rapid increase in home-produced food ${ }^{64}$ What made nitrogen particularly attractive to members of the NRTC was that it enabled them to set up quantitative formulae of a simple input / output type which equated an increase in nitrogen consumption with an increase in food production (measured in 'starch equivalent'): 'the total increase in production from the use of a further 80,000 tons of $\mathrm{N}$ would therefore be 0.9 million tons starch equivalent or about 3.5 per cent of the present total energy production of agriculture in the United Kingdom'. ${ }^{65}$ When asked their opinion on composting, the members of the NRTC argued that 'the problem should be treated quantitatively' and that the Committee should therefore focus on nitrogen content since 'the value of humus depended essentially on its physical

\footnotetext{
59 Minutes of a meeting of the NRTC, 30 November 1950, University of East Anglia, Solly Zuckerman archives, $\mathrm{SZ} / \mathrm{NRTC} / 2$.

60 Natural Resources (Technical) Committee, The Use of Towns' Waste in Agriculture (London, HMSO, 1954), p. 1.

61 F. C. O. Speyer, Some Nitrogen Problems (London: Vaccher \& sons, 1td., 1928), pp. 2-5; Mirko Lammer, The World Fertiliser Economy (Stanford: Stanford University Press, 1957), pp. 171-174.

62 'Survey of the Commercial Fertiliser Industry', 1950, p. 35, Nitrogen. Commonwealth Economic Committee SubCommittee on Fertilisers, National Archives, Kew (hereafter NA) BT 64/1274; Lamer, The World Fertiliser Economy, pp. 513-514.

63 James C. Scott, Seeing like a State: How Certain Schemes to Improve the Human Condition have Failed (New Haven: Yale University Press, 1998); Timothy Mitchell, Rule of Experts: Egypt, Techno-Politics, Modernity (Berkeley: University of California Press, 2002), p. 117.

64 'Resources required for the expansion of agriculture', 24 June 1952, UEA, SZ/NRTC/4.

65 'The Expansion of Agriculture: Introductory Note', 1951, UEA, SZ/NRTC 3.
} 
condition which is not easily amenable to quantitative measurement'. ${ }^{66}$

Composting was thus not rejected because it was unknown nor because of any nebulous ideological or cultural 'throwaway ethic' which dictated that modern societies should get rid of all their refuse without further thought. The possibility of adopting compost was indeed assessed by governmental experts but was dismissed because it was ill-adapted to the rising system of expertise in Great Britain that relied on a small number of quantifiable indicators, such as nitrogen in the case of the NRTC. Composting was thus rejected by the Committee, and subsequently by the British government, on the basis that it 'cost more to use town's refuse, per unit of nitrogen (...) than it cost to produce a unit of fertiliser by ordinary industrial methods'. ${ }^{67}$

The Zuckerman report was a perfect example of a quantitative and reductionist approach focused on soil nutrients, which was criticised by supporters of composting as the 'NPK mentality' ${ }^{68}$ The critics of the Report denounced the 'fallacies' of the Zuckerman Report, and its short-sighted focus on nitrogen content instead of the physical role of organic matter in the soil and argued that the nutrients contained in compost 'should be regarded as a free bonus rather than as criterion of their value as a manure'. ${ }^{69}$ The value of compost, they argued, could not be assessed strictly in terms of its main chemical constituents, and its physical properties had to be taken into account as well. They argued that any assessment of compost should take into account its positive impacts on the structure of the soil, on its 'air and water-retention capacity', and more generally its long-term preventive role against erosion, all elements that obviously lent themselves much less easily to quantification than nitrogen. ${ }^{70}$

\section{Whitehall opposition}

Despite these criticisms and other shortcomings in the work of the Committee, which had for example not taken into account the potential contribution of paper to composting, it was to form the basis of the Government's firm rejection of composting for the next twenty years. ${ }^{71}$ The Report appeared at a moment when the British government was certainly relaxing its attitude towards the question of recycling: the regulations forbidding the destruction of paper or rags were abolished in 1949 and the Directorate of Salvage and Supply was disbanded the following year. ${ }^{72}$ On the basis of the Zuckerman Report, the newly created Ministry of Housing and Local Government (hereafter MHLG), which was in charge of the collection and disposal of town refuse, became firmly opposed to composting and discouraged local authorities from investing in it. Officials from the MHLG were invited to various composting plants in Scotland, Denmark or the Netherlands, but despite praise from local authorities who were satisfied with composting, the Chief Public Cleansing Inspector remained unconvinced, and argued that the Ministry of Housing should continue to dissuade local authorities from considering new composting schemes. ${ }^{73}$

\footnotetext{
66 'Draft report on sewage sludge, household refuse and composts made from them as potential sources of fertiliser', 1953, UEA, SZ/NRTC/4.

${ }_{67}$ Minutes of a meeting of the NRTC, 28 January 1953, UEA, SZ/NRTC/1.

68 For an overview of the controversy (from the pro-fertiliser side) see Donald P. Hopkins, Chemicals, Humus and the Soil (London: Faber \& Faber, 1957 (1945)).

69 S. A. Gothard \& L. P. Brunt, 'The Zuckerman report on towns' wastes: some comments', Surveyor and Municipal and County Engineer 113 (1954): 701; 'Correspondence', British Medical Journal, 20 October 1956: 940-941.

70 A. G. Davies, Municipal Composting (London: Faber \& Faber, 1961), p. 140. J. C. Wylie, Fertility from Town Wastes (London: Faber \& Faber, 1955), p. 140.

71 K. R. Gray \& A. J. Biddlestone, "Agricultural Uses of Composted Town Refuse", in Ministry of Agriculture and Fisheries, Inorganic Pollution and Agriculture, p. 280 (London, HMSO, 1979).

72 Thorsheim, Waste into Weapons, p. 254.

73 J. Sumner, 'Composting of Town Wastes: Report of a visit to Edinburgh'.
} 
If controlled tipping was undoubtedly the cheapest form of refuse disposal, some local authorities, which lacked available space for it, were looking for other solutions, and some of them considered composting which was not more expensive to build or operate than incineration plants. ${ }^{74}$ Theoretically, local authorities could choose the method of disposal they wanted, but composting usually required high investments and local authorities relied on interest-free loans to help them start the project. In Holland, most initiatives had originated from public subsidies and loans, but Whitehall was definitely opposed to developing such schemes. ${ }^{75}$ The Ministry publicly professed that local authorities were entirely free to decide which method was better adapted to their conditions and that they had no a priori opposition to composting. However, as recognised in private by an official, the attitude of the Ministry did amount, in practice, to 'discouragement' and local authorities were systematically discouraged from considering composting as a viable method of refuse disposal. ${ }^{76}$

The role of the government was thus critical as, in the absence of financial assistance from the Ministry, local authorities, suffering from the difficult economic conditions of the 1960s, were hesitant to initiate long-term undertakings and investment. ${ }^{77}$ The reluctance of local authorities was made even more critical by the absence of reliable data regarding the costs and benefits of the technology. Supporters of compost did try to gather and present information regarding composting's operating costs in Great Britain and other countries but those varied enormously depending on local circumstances and the technology adopted. ${ }^{78}$ As for the Ministry of Housing, they actually had no data of their own and relied, throughout the 1960s, on the Zuckerman Report for all its data on cost assessment. The conclusions reached in the Zuckerman report were, however, based not on the study of the more recent developments but on the small-scale and 'primitive' plants that had mostly been set up before WWII. ${ }^{79}$ Significantly, the Ministry was firmly opposed to the implementation of any pilot scheme, which could have given local authorities more precise information. ${ }^{80}$

This uncertainty regarding the operating costs of this technology was made more problematic by the fact that most governmental estimates were made without taking into account the potential sale of the end product to farmers or gardeners. One of the main criticisms expressed by compost supporters was that, in strict economic terms, tipping and composting could not be held to the main standard: 'by processing domestic refuse to make composts, local health authorities discharge two functions. On the one hand, they dispose of their potentially harmful wastes effectively, and on the other, produce an organic manure'. ${ }^{81}$ However, as the MHLG was in charge only of the former, it considered compost only as a means of disposing of refuse, and therefore compared its initial costs with those of other methods, without really considering the potential benefits in agricultural terms.

The question of cost was indeed related to the question of the potential sale of the end product and therefore of demand. The main argument that was held against composting was that the demand for the product was fluctuant, and that compost was viewed with considerable diffidence by farmers. Supporters of composting acknowledged that demand had to be created and encouraged, and gave some examples of demand exceeding supply in Holland, Jersey or Edinburgh. Yet, in order to

\footnotetext{
74 Department of the Environment, Refuse Disposal: Report of the Working Party on Refuse Disposal, pp. 52, 67 \& 110; Gordon, 'Municipal Composting in the United Kingdom': 1-29; 'Joint Working Party on Municipal Composting', Municipal Engineering, 29 January, 1965: 219-22.

75 Davies, Municipal Composting, pp. 56-61.

${ }^{76}$ Letter from H. H. Browne to A. B. Bartlett, Ministry of Agriculture, Fisheries and Food, 31 ${ }^{\text {st }}$ March, 1965, NA, HLG 51/1128.

77 Stokes et. al., The Business of Waste, p. 85.

78 J. Kupchik, 'Economics of Composting Municipal Refuse in Europe and Israel', Bulletin of the World Health Organization 34 (1966): 800; For a detailed analysis of the economics of composting see Davies, Municipal Composting, 156-183.

79 'Producing humus and saving the ratepayers' money', Manchester Guardian, 20 January 1959.

80 'Note of a Meeting held at the Ministry of Housing and Local Government', 19 ${ }^{\text {th }}$ July 1963, NA, HLG 51/1128.

81 Wylie, Fertility from Town Wastes, pp. 147-148.
} 
demonstrate the value of composting, it was necessary for research institutions to set up programmes, in order to have a better understanding of the potential benefits of compost, beyond a simple chemical analysis indicating nitrogen content. ${ }^{82}$ One of the main problems with composting, as recognised even by some of its most ardent supporters, lay in the difficulty to 'compute' with precision 'the extent to which the composts produced (could) stimulate the favourable factors in soils' and to relate those 'to the increase in crop production which would result from their use'. ${ }^{83}$

In this field too, opposition by Whitehall played a significant role. Supporters of composting argued that the only way to tackle this issue was by overcoming administrative fragmentation and by developing consultations between the MHLG and the Ministry of Agriculture on the question, but none of them showed any interest in initiating a partnership. ${ }^{84}$ The Ministry of Agriculture indeed refused to set up and finance field experiments, considering that compost was of very limited use since it did not 'contribute appreciably to the NPK requirements of crops'. ${ }^{85}$ The only use envisaged for composting was in the production of filling material in order to reclaim waste or marginal land, which was briefly investigated in the 1960s with, however, very little practical outcome. ${ }^{86}$ So, when the Ministry of Agriculture was approached by some composting firms, who were willing to offer several tons of compost in order for tests to be performed, the offer was turned down. ${ }^{87}$ The most important consequence of this lack of interest was that compost was faced with the insuperable barrier of not being able to be marketed as a 'fertiliser', and thus of not being entitled to the government subsidy which synthetic fertilisers benefited from, resulting in the competition between the two being heavily distorted in favour of the latter ${ }^{88}$ By the late 1960s, composting had become increasingly marginalised, and was dismissed by the Working Party on Refuse Disposal, which published its Report in 1971 ${ }^{89}$ Once again, the Working Party based much of its assessment on the data gathered nearly twenty years earlier by the NRTC. Controlled tipping was hailed as the most economical and satisfactory method, and it was estimated that composting could 'make little contribution to the disposal of refuse'.$^{90}$ In the early 1970 s, there were still about a dozen plants in operation, but, in the absence of governemental assistance and fertilizer subsidy, most of them struggled to find markets for their product and eventually closed down in the course of the decade. The main problem was of course that of demand, since farmers remained reluctant to buy compost. The other problem was that composting required a degree of pre-separation that was deemed too labour-intensive ${ }^{91}$. There was, however, continued research into the question throughout the 1970s, and the scientists at the University of Birmingham who pursued it kept on building on the results of previous experiments in Great Britain. Their work coincided with rising concerns over environmental issues in general and over waste in particular, with, for example, the publication of a Green Paper by the Labour Government, War on Waste (1974), which argued for a more active role for the state in the promotion of recycling. Interestingly, however, there was no sense among compost researchers that they had 'invented' anything new and the scientists who pursued it presented their work as building up on decades of interest and research into the question, and not as

82 Davies, Municipal Composting, pp. $124 \& 182$.

83 Wylie, Fertility from Town Wastes, p. 139.

84 House of Commons, 'Refuse and Sewage Sludge', Hansard, 20 May 1958, vol. 588, c. 1082.

85 Ministry of Agriculture and Fisheries, Advisory Service and Labour Division, 'Compost from Town Refuse: Note for the Minister', April 1965, NA, MAF 141/493.

86 Ministry of Agriculture and Fisheries, "Use of composted town refuse in land reclamation and restoration", NA, MAF 141/493.

87 Letter of Joseph Binns to Rt. Hon Fred Peart, Minister of Agriculture, Fisheries and Food, 23 February 1965, and Draft Note of Reply by the Ministry of Agriculture's Advisory Service and Labour Division, March 1965, NA, HLG $51 / 1128$.

88 Lawrence D. Hills, “War on Junk", New Statesman, 1 January 1966: 731

89 W. R. Shirrefs, 'Leicester's Compost Plant', Journal of the Royal Society of Promotion of Health 85 (1965): $173-177$.

90 Department of the Environment, Refuse Disposal: Report of the Working Party on Refuse Disposal, p. 127.

91 "Address by D. H. G. Tollemache to the Annual General Meeting of the H.D.R.A. $11^{\text {th }}$ March 1967 on Municipal Composting", Archives of the Museum of English Rural Life, Reading, P 3940, Box 1/08. 
anything really new. ${ }^{92}$

\section{CONCLUSION}

As has been argued recently, the use of the notion of 'rationalisation' to describe the 'Refuse Revolution' which occurred in the twentieth century is not unproblematic, as the meaning and nature of this rationalisation remained heavily contested throughout the twentieth century. ${ }^{93}$ The example of the rise and wane of composting in Great-Britain shows that the gradual abandonment of recycling practices was not consensual and leads us to question the notion that in the course of the twentieth century, all domestic rubbish came to be viewed simply as noxious and useless material, and waste processing as simply a matter of displacing this material as quickly and cheaply as possible. The birth of the 'throwaway society' may thus not be said to have been a 'natural' phenomenon, as it required the silencing and marginalisation of alternatives and concerns around the question of waste management. The ambition to recycle domestic and municipal refuse not only did not disappear after WWI, but may even be said to have gone through a revival with the question of composting.

If more work remains to be done on the local aspect of the question in order to understand more precisely the different reasons which motivated technological choice in the field of waste disposal, this paper has thus attempted to show that cultural and technical attitudes towards waste remained indeed more complex and heterogenous than they are generally protrayed to be in the broad narrative of the 'Refuse Revolution'. It has also attempted to show that rather than rely on general cultural or ideological attitudes towards waste, explanations for the decline or marginalisation of recycling practices should pay closer attention to the increasing role of the State in wastemanagement throughout the twentieth cenury. This paper thus shows that the abandonment of recycling practices, which is often presented as the necessary consequence of modernisation and technical progress, was in fact not simply a technical process, but a political one as well. Composting was indeed a quite costly alternative to tipping, but potential interest in the technology was also smothered by indifference, administrative fragmentation and the rise of nitrogen as a leading indicator. The study of the work and legacy of the Natural Resources (Technical) Committee, in particular, show that those initiatives were abandoned because they did not fit in with the type of expertise which informed post-WWII policy-making, and which relied increasingly on the existence of quantifiable indicators, such as nitrogen, to evaluate political decisions regarding both agricultural and waste-management policies.

\footnotetext{
92 K. R. Gray, K. Sherman, A. J. Biddlestone, 'A Review of Composting - Part 1. Microbiology and Biochemistry', Process Biochemistry 6 (1971): 32-36; K. R. Gray, K. Sherman, A. J. Biddlestone, 'A Review of Composting - Part 2. The Practical Process', Process Biochemistry 6 (1971): 22-28; K. R. Gray, A. J. Biddlestone \& R. Clark, 'A Review of Composting - Part 3: Processes and Products', Process Biochemistry 6 (1973): 11-15.

93 Stokes et. al., The Business of Waste, p. 49.
} 